\title{
Hubungan antara Pembelajaran Observasional dengan Intensi Berwirausaha pada Mahasiswa Universitas Indonesia
}

\section{Correlation between Observational Learning and Entrepreneurial Intention among University of Indonesia's Students}

\author{
Dewi Kumalasari ${ }^{1}$, Wustari Mangundjaya ${ }^{2}$, Gagan Hartana ${ }^{2}$ \\ ${ }^{I}$ Fakultas Psikologi, Universitas YARSI, Jakarta, Indonesia \\ ${ }^{2 \& 3}$ Fakultas Psikologi, Universitas Indonesia, Depok, Jawa Barat, Indonesia \\ Email:dewi.kumalasari@yarsi.ac.id
}

\section{KATA KUNCI KEYWORDS}

ABSTRAK
Intensi Berwirausaha, Pembelajaran Observasional, Mahasiswa Entrepreneurial Intention, Observational Learning, College Students

Paparan model peran wirausahawan yang sukses merupakan salah satu faktor kunci dalam pembelajaran kewirausahaan dan perkembangan karir (Boyd \& Vozidis dalam Laviolette \& Radu, 2008). Penelitian ini bertujuan untuk mengetahui hubungan antara pembelajaran observasional melalui model peran wirausaha dengan intensi berwirausaha pada mahasiswa Universitas Indonesia. Desain penelitian ini adalah studi lapangan dengan menggunakan accidental sampling sebagai metode pengambilan data. Partisipan penelitian ini terdiri dari 101 mahasiswa Universitas Indonesia dari 10 fakultas yang berada di kampus UI Depok. Hasil dari penelitian ini membuktikan bahwa terdapat hubungan yang signifikan antara pembelajaran observasional dengan intensi berwirausaha. Dalam penelitian ini, ditemukan bahwa dimensi motivasi merupakan dimensi yang paling besar memberikan kontribusi terhadap intensi berwirausaha diantara dimensi lain dari pembelajaran observasional.

Among the key contextual factors of entrepreneurial intention's genesis, the exposure to successful role models was identifies as a master piece of entrepreneurial learning and career development (Boyd \& Vozidis; Laviolette \& Radu, 2008). This study aims to prove the correlation between observational learning by means of entrepreneurial role model and entrepreneurial intention among University of Indonesia's students. The design of this research is field study by accidental sampling as data collection method. The study consists of 101 students of University of Indonesia as respondents that come from 10 faculties at UI's campus, Depok. The result from this study proves that there is a significant correlation between observational learning and entrepreneurial intention. In this research, motivational dimension has most significant contribution towards entrepreneurial intention among other dimensions of observational learning. 


\section{PENDAHULUAN}

Kewirausahaan memiliki peran besar dalam pertumbuhan ekonomi suatu bangsa. Linan dkk (2005) menyatakan bahwa kewirausahaan merupakan instrumen yang paling relevan untuk memajukan pertumbuhan dan perkembangan ekonomi di berbagai daerah. Dalam hal ini, peran kewirausahaan dalam pertumbuhan ekonomi mencakup lebih dari sekedar meningkatkan pendapatan perkapita. Kewirausahaan berperan memprakarsai perubahan dalam struktur bisnis dan masyarakat (Hisrich, Peter \& Sheperd, 2005). Perubahan tersebut sejalan dengan pertumbuhan dan peningkatan pendapatan yang memungkinkan lebih banyak kekayaan yang terdistribusi secara lebih tersebar.

Meskipun demikian, pada kenyataannya sedikit sekali SDM yang mengembangkan dirinya sebagai seorang wirausaha. Pada 2001, kurang dari 10 persen dari populasi orang dewasa yang memulai usaha baru (Nolan dalam Linan dkk, 2005). Fakta tersebut menjadi hal yang ironis bila dihubungkan dengan jumlah pengangguran yang ada di Indonesia. Jika melihat kondisi bangsa Indonesia, kewirausahaan dapat dikatakan sebagai salah satu jawaban atas permasalahan yang dari tahun ke tahun dialami Indonesia, yaitu pengangguran. Padahal, tidak dapat dipungkiri bahwa tingginya angka pengangguran disebabkan karena pada umumnya orang tergantung pada ketersediaan lapangan pekerjaan, bukan menciptakan lapangan kerja baru. Hal ini sejalan dengan hasil sensus ketenagakerjaan nasional 2007 bahwa hanya 5 persen dari jumlah angkatan kerja Indonesia yang berminat pada kewirausahaan.

Mengembangkan kewirausahaan merupakan salah satu upaya untuk mengurangi tingkat pengangguran, disamping meningkatkan kualitas sumber daya manusia dan menciptakan lapangan kerja baru (Sudrajat, 2003). Berdasarkan penelitian Audretsch (dalam Linan dkk, 2005), didapatkan hasil bahwa indeks inisiatif berwirausaha berbanding terbalik dengan tingkat pengangguran. Semakin tinggi peningkatan inisiatif berwirausaha pada suatu daerah maka terdapat kecenderungan penurunan jumlah pengangguran yang besar. Dengan demikian, dapat dikatakan bahwa berwirausaha merupakan cara yang efektif untuk menurunkan tingkat pengangguran di sebuah daerah.

Berdasarkan sudut pandang psikologi, tingkah laku berwirausaha merupakan tingkah laku disengaja yang dimunculkan karena adanya intensi. Dalam tingkah laku berwirausaha, intensi untuk menjadi pengusaha merupakan satu-satunya prediktor terbaik untuk meramalkan tingkah laku aktual seseorang dalam berwirausaha (Linan, dkk, 2005). Hal ini diperkuat dengan pernyataan Krueger Jr et al (dalam Linan, 2005) yang menyatakan bahwa intensi adalah prediktor tunggal terbaik dari berbagai tingkah laku yang direncanakan, termasuk kewirausahaan. Hisrich, Peter \& Sheperd (2008) mendefinisikan intensi berwirausaha sebagai faktor motivasional yang mempengaruhi individu untuk mencapai hasil-hasil berwirausaha. Dengan kata lain, intensi berwirausaha merupakan sesuatu yang indikator terkuat yang menentukan seseorang akan berwirausaha atau tidak.

Diantara berbagai faktor kontekstual kunci dari intensi berwirausaha, paparan tentang model peran yang sukses diidentifikasi sebagai faktor penting dalam pembelajaran kewirausahaan dan perkembangan karir (Boyd \& Vozidis dalam Laviolette \& Radu, 2008). Lebih jauh, dalam konteks kehidupan mahasiswa, banyak studi yang menemukan bahwa model peran adalah faktor paling penting dalam menumbuhkan intensi berwirausaha (Garo, Kume \& Basho, 2015). Dalam konteks kewirausahaan, model peran dapat diartikan sebagai individu-individu yang mempengaruhi gaya dan pilihan karir wirausaha (Hisrich, Peter \& Sheperd, 2005). Model peran ini dapat berbentuk model langsung yaitu seseorang yang 
secara langsung menampilkan perilaku, atau model simbolik yaitu seseorang atau perilaku yang muncul secara tidak langsung atau melalui suatu media (Ormrod dalam Riyanti, 2008).

Dalam sudut pandang teori pembelajaran sosial yang dikembangkan oleh Bandura (dalam Ormrod, 1999), model peran merupakan sosok yang dijadikan rujukan dalam aktivitas modeling. Aktivitas modeling merupakan inti dari pembelajaran sosial (Feist \& Feist, 2006). Menurut teori pembelajaran sosial, pembelajaran dapat terjadi tidak hanya melalui pengalaman langsung, tetapi juga melalui observasi terhadap orang lain yang dirujuk sebagai model. Melalui modeling, seseorang dapat mempelajari sesuatu yang berharga dari sosok-sosok yang pernah berhasil dalam menghadapi kondisi yang sulit (Ormrod, 2006).

Bandura (dalam Feist \& Feist, 2006) menyatakan terdapat empat proses yang membentuk pembelajaran observasional, yaitu atensi, representasi, produksi tingkah laku dan motivasi. Proses atensi merupakan proses awal dalam pembelajaran sosial dimana individu memberikan atensi terhadap model peran yang dituju serta aktivitas yang dilakukan model peran tersebut. Sementara itu, proses representasi merupakan pembentukan representasi simbolik dalam ingatan individu yang dibentuk dari informasi yang didapatkan setelah individu memberikan atensi terhadap model peran. Dalam literatur lain, Bandura (1986) menyatakan proses setelah atensi adalah proses retensi. Proses ketiga dalam pembelajaran observasional adalah produksi tingkah laku dimana individu mengubah representasi simbolik yang berada dalam ingatannya ke dalam tingkah laku yang sesuai. Proses terakhir yang akan sangat mempengaruhi efektivitas dari pembelajaran observasional adalah motivasi. Proses atensi dan representasi dapat mengarahkan individu pada pengetahuan yang dipelajari dari pengamatan terhadap model peran, namun tampilnya tingkah laku difasilitasi oleh motivasi untuk menampilkan tingkah laku tersebut.

Berdasarkan paparan diatas, permasalahan yang diangkat dalam penelitian ini adalah apakah terdapat hubungan pembelajaran observasional melalui model peran dengan intensi berwirausaha pada kaum muda. Permasalahan ini menjadi menarik untuk diangkat sebagai salah satu upaya identifikasi dan eksplorasi faktor sosial, dalam hal ini model peran, yang dapat membangkitkan intensi berwirausaha. Adapun pengambilan data yang dilakukan dalam penelitian ini adalah dengan teknik kuantitatif yaitu menggunakan dua buah alat ukur. Alat ukur pertama berupa kuesioner yang menggali tentang pembelajaran observasional yang didapatkan dari model peran. Kuesioner ini dibuat oleh peneliti berdasarkan konstruk pembelajaran observasional yang dikemukakan Bandura (1986). Alat ukur kedua merupakan kuesioner yang menggali intensi berwirausaha (Entrepreneurial Intention Questionnaire/EIQ).

Dalam penelitian ini, populasi penelitian adalah kaum muda Indonesia, khususnya individu dewasa awal (emerging adulthood). Kaum muda menjadi tujuan dan sasaran dalam penelitian ini karena potensi besar yang dimilikinya. Berdasarkan kalkulasi dari Himpunan Pengusaha Muda Indonesia (HIPMI), potensi kaum muda yang bisa dicetak menjadi pengusaha muda (usia antara 20 41 tahun) menurut data BPS sekitar 70 juta jiwa. Jika 10\%-nya saja terjun ke dunia usaha dengan masing-masing menciptakan 5 lapangan pekerjaan, maka sekitar 7 juta pengusaha akan lahir dan dapat berpotensi membuka lapangan pekerjaan bagi 35 juta jiwa. Lebih khusus dalam penelitian ini sampel yang digunakan adalah mahasiswa Universitas Indonesia dengan penjelasan yang dapat dilihat pada bagian berikutnya. 


\section{METODE PENELITIAN}

\section{Subjek}

Partisipan dalam penelitian ini adalah mahasiswa Universitas Indonesia. Alasan pemilihan sampel penelitian ini adalah karena karakteristik sampel sesuai dengan karakteristik populasi dari penelitian ini yaitu berada dalam rentang usia dewasa awal serta diasumsikan lebih dapat memahami konsep yang tertuang dalam kuesioner karena memiliki kapasitas kognitif yang memadai. Selain itu, saat ini universitas Indonesia sedang menggiatkan program kewirausahaan, yaitu dengan memberikan pinjaman dana dan bimbingan bagi mahasiswa yang ingin berwirausaha. Adapun karakteristik partisipan dalam penelitian ini adalah sebagai berikut:

1. Memiliki kekaguman terhadap sosok pengusaha tertentu. Identifikasi ini dapat dilakukan dengan mengajukan pertanyaan langsung sebelum memberikan kuesioner.

2. Berada dalam rentang usia 20-30 tahun

3. Tidak sedang memiliki aktivitas kewirausahaan

Prosedur yang digunakan dalam pemilihan sampel penelitian ini adalah nonprobability sampling yaitu tidak semua anggota populasi memiliki kesempatan untuk dipilih (Kountur, 2003). Sementara itu, teknik penarikan sampel yang digunakan adalah accidental sampling. Melalui accidental sampling peneliti memilih partisipan berdasarkan ketersediaan dan kesedian partisipan untuk menjadi subjek penelitian ini (Sugiyono, dalam Ardias, 2008).

\section{Desain}

Penelitian ini tergolong dalam jenis penelitian non-experimental dimana peneliti hanya melakukan pengamatan dan berusaha menjelaskan hal-hal yang menjadi penyebabnya (Kumar, 1999). Dalam penelitian ini, tidak dilakukan manipulasi pada variabel penelitian. Variabel penelitian tidak dapat dikontrol secara langsung karena merupakan variabel yang sudah ada dalam diri responden sebelum penelitian dilakukan. Tiadanya manipulasi pada variabel penelitian menyebabkan penelitian ini tergolong pada riset konklusif dengan tipe desain ex post facto (Sugiyono, dalam Ardias 2008).

\section{Instrumen Penelitian}

Instrumen yang digunakan peneliti dalam meneliti hubungan antara pembelajaran observasional dengan intensi berwirausaha pada mahasiswa Universitas Indonesia adalah dengan menggunakan dua alat ukur. Dua alat ukur yang dimaksud adalah skala yang menggali pembelajaran observasional dan skala yang menggali intensi berwirausaha. Intensi berwirausaha diukur dengan menggunakan Entrepreneurial Intention Questionnaire (EIQ) yang dikembangkan oleh Linan \& Chen (2006). Dalam penelitian ini, EIQ yang dikembangkan oleh Linan \& Chen (2006) dimodifikasi dan disesuaikan dengan konteks Indonesia, baik dari segi bahasa maupun konteks sosial. Dari hasil modifikasi EIQ yang dilakukan peneliti, dihasilkan 29 item yang terdiri dari itemitem yang mewakili ketertarikan personal, kontrol tingkah laku yang dipersepsikan, norma subjektif, penilaian orang-orang terdekat, penilaian sosial dan keterampilan berwirausaha. Sementara itu, alat ukur pembelajaran observasional yang digunakan dalam penelitian ini adalah hasil konstruksi yang dilakukan peneliti berdasarkan proses dalam pembelajaran observasional yang dikemukakan Bandura (1986).

Kedua alat ukur ini berbentuk skala summated rating dimana skor seseorang diperoleh dengan menjumlahkan respon yang diberikan (Neuman dalam Ardias, 2008). Kedua alat ukur ini digabungkan menjadi satu kuesioner. Kuisioner dipilih karena sifatnya yang efisien, dimana kuisioner dapat diberikan pada banyak partisipan dalam waktu yang singkat (Ardias, 2008). 


\section{Pengujian Reliabilitas dan Validitas Alat Ukur}

Uji reliabilitas yang dilakukan untuk menguji konsistensi alat ukur intensi berwirausaha dan pembelajaran observasional adalah dengan metode alpha cronbach. Uji validitas yang digunakan dalam menguji alat ukur intensi berwirausaha dan pembelajaran observasional adalah uji validitas kriteria. Dari hasil uji reliabilitas dan validitas kedua alat ukur didapatkan hasil sebagai berikut:

Tabel 1. Validitas dan Reliabilitas Alat Ukur

\begin{tabular}{lll}
\hline Variabel & $\begin{array}{l}\text { Indeks } \\
\text { reliabilitas }\end{array}$ & $\begin{array}{l}\text { Indeks } \\
\text { validitas }\end{array}$ \\
\hline Intensi berwirausaha & 0,964 & 0,783 \\
\hline $\begin{array}{l}\text { Pembelajaran } \\
\text { Observasional }\end{array}$ & 0,846 & 0,829
\end{tabular}

Dari tabel 1 tersebut terlihat bahwa kedua alat ukur yang digunakan dalam alat ukur ini dapat dikatakan valid dan reliable berdasarkan batasan indeks reliabilitas yang dinyatakan Anastasi \& Urbina (1997) dan signifikansi nilai korelasi terhadap kriteria.

\section{ANALISIS \& HASIL}

Untuk mengetahui hubungan antara pembelajaran observasional dengan intensi berwirausaha, peneliti menggunakan perhitungan regresi linear dalam SPSS versi 16.00. Perhitungan regresi linear digunakan untuk menghitung korelasi berganda. Teknik ini dipilih karena variabel yang diperhitungkan bersifat interval. Selain itu, melalui teknik ini didapatkan indeks korelasi tunggal serta dapat diketahui kontribusi masing-masing dimensi pembelajaran observasional terhadap intensi berwirausaha. Berikut adalah hasil korelasi yang didapatkan:

Tabel 2. Hasil perhitungan korelasi berganda

\begin{tabular}{ccc}
\hline Nilai $\mathbf{R}$ & $\boldsymbol{R}$ square & Adjusted $\boldsymbol{R}$ square \\
\hline 0,562 & 0,316 & 0,288 \\
\hline
\end{tabular}

Berdasarkan tabel 2 diatas, terlihat bahwa intensi berwirausaha pada subjek penelitian memiliki hubungan sebesar $31,6 \%$ dengan pembelajaran observasional yang terdiri dari dimensi atensi, retensi, produksi dan motivasi. Dari hasil tersebut juga dapat disimpulkan bahwa bila diterapkan pada populasi, maka secara signifikan pembelajaran observasional dapat menjelaskan $28,8 \%$ pembelajaran observasional (adjusted $\mathrm{R}^{2}=0,288$ ). Hal ini berarti $71,2 \%$ pembelajaran observasional dapat dijelaskan oleh variabel lain diluar pembelajaran observasional.

Dari hasil diatas, dapat disimpulkan bahwa dengan derajat kepercayaan 99\% variabel pembelajaran observasional memiliki hubungan yang signifikan dengan intensi berwirausaha, yaitu sebesar 0,562. Dengan demikian H0 dalam penelitian ini ditolak. Untuk mengetahui kontribusi masing-masing dimensi pembelajaran observasional terhadap intensi berwirausaha, dapat dilihat melalui perhitungan part correlation. Part correlation digunakan untuk melihat hubungan antara satu dimensi pembelajaran observasional dan intensi berwirausaha dengan memperhitungkan keberadaan dimensi-dimensi yang lain, yang terangkum dalam tabel berikut ini:

Tabel 3.Hasil perhitungan part correlation dimensi pembelajaran observasional

\begin{tabular}{ccc}
\hline Dimensi & Sign & Part correlation \\
\hline Atensi & 0,591 & 0,045 \\
Retensi & 0,143 & 0,125 \\
Produksi & 0,020 & 0,200 \\
Motivasi & 0,012 & 0,217 \\
\hline
\end{tabular}

Dari tabel 3 tersebut terlihat bahwa dimensi motivasi merupakan dimensi yang paling berkontribusi dalam menjelaskan intensi berwirausaha. Sementara itu, dimensi atensi merupakan dimensi yang paling lemah kontribusinya dalam menjelaskan intensi berwirausaha.

\section{DISKUSI}

Dalam penelitian ini, pembelajaran observasional terbukti memiliki hubungan yang signifikan dengan intensi berwirausaha. Hasil ini memperkuat hasil penelitian yang dilakukan oleh Garo, Kume dan Basho (2015) yang menunjukkan adanya hubungan yang positif antara paparan model peran wirausaha dengan 
intensi berwirausaha pada mahasiswa Albania.

Berdasarkan hasil perhitungan part correlation keempat dimensi pembelajaran observasional dengan intensi berwirausaha, didapatkan hasil bahwa indeks korelasi semakin meningkat seiring dengan peningkatan proses pembelajaran observasional. Dengan demikian dimensi motivasi memiliki hubungan yang paling besar terhadap intensi berwirausaha sementara dimensi atensi memiliki hubungan yang paling kecil terhadap intensi berwirausaha.

Indeks korelasi yang didapatkan dari tiap dimensi terlihat meningkat dimana pada dimensi atensi memiliki indeks part correlation terkecil dan dimensi motivasi memiliki indeks part correlation. Dari hasil tersebut peneliti menduga bahwa semakin intens seseorang melakukan pembelajaran observasional, maka semakin besar kemungkinan munculnya pembelajaran observasional pada dirinya. Dikatakan semakin intens karena proses pembelajaran observasional merupakan proses yang berkelanjutan, dimulai dengan proses atensi, dilanjutkan proses retensi, kemudian proses produksi dan yang terakhir namun sangat menentukan adalah proses motivasi.

Pada proses atensi, individu memiliki ketertarikan terhadap model peran wirausaha tertentu. Ketertarikan ini menjadi kunci dalam proses atensi karena individu cenderung akan memberikan atensi pada hal-hal yang mereka anggap penting/ mereka tertarik dengannya. Namun demikian, atensi saja tidak cukup untuk mencapai hasil maksimal dalam pembelajaran observasional. Informasiinformasi yang didapatkan dari proses atensi kemudian dilanjutkan dalam proses retensi dimana individu membentuk model internal tentang tingkah laku kewirausahaan. Model internal ini dibentuk individu dari ekstraksi terhadap informasiinformasi yang ia dapatkan selama proses atensi. Model internal inilah yang tersimpan dalam ingatan individu sehingga individu tersebut memiliki skema tertentu tentang kewirausahaan, misalnya hal-hal yang dibutuhkan untuk menjadi wirausaha.

Setelah individu membentuk model internal tentang kewirausahaan, proses selanjutnya adalah proses produksi. Pada proses ini, individu harus merasa mampu untuk melakukan hal-hal yang sesuai dengan model internal yang telah ia simpan di ingatannya. Jika individu telah merasa mampu untuk melakukan aktivitas yang sesuai dengan model internal yang telah ia bentuk, maka proses selanjutnya adalah proses motivasi. Proses inilah yang menentukan apakah hasil pembelajaran observasional yang terjadi dalam dirinya akan ditampilkan dalam tingkah laku. Dalam proses motivasi, individu terdorong untuk mendapatkan insentif yang bernilai bagi dirinya. Jika individu merasa insentif yang didapatkan model peran wirausaha dari aktivitas kewirausahaannya tidak bernilai bagi individu tersebut, maka individu tersebut cenderung untuk tidak menampilkan tingkah laku berwirausaha.

Dalam penelitian ini, pengukuran kemungkinan tampilnya tingkah laku berwirausaha dari pembelajaran observasional yang terjadi pada subjek adalah dengan mengukur intensi berwirausaha. Pengukuran intensi dilakukan karena dalam tingkah laku berwirausaha, intensi untuk menjadi pengusaha merupakan satu-satunya prediktor terbaik untuk meramalkan tingkah laku aktual seseorang dalam berwirausaha (Linan, dkk, 2005).

Dari indeks korelasi per bagian yang didapat, dimensi motivasi merupakan dimensi yang memiliki kontribusi terbesar dalam menjelaskan pembelajaran observasional. Dalam dimensi motivasi, individu terdorong untuk menunjukkan perilaku yang didapat dari hasil pembelajaran observasional yang terjadi dalam dirinya jika ia menilai bahwa dengan mewujudkan hasil pembelajaran dalam tingkah laku, ia akan mendapatkan insentif bagi dirinya sendiri. Insentif yang dimaksud dapat berupa materi ataupun kepuasan personal dan kemandirian. Hasil ini dapat 
dijadikan salah satu rujukan dalam membuat program yang memicu intensi berwirausaha, yaitu dengan menyajikan informasi-informasi mengenai insentif yang akan didapatkan dari berwirausaha.

Selain mengolah data primer penelitian, peneliti juga mengolah variabel sekunder yang dapat menunjang hasil penelitian. Variabel sekunder yang turut diolah dalam penelitian ini adalah jenis kelamin, jenis model peran, suku bangsa serta pekerjaan orang tua dalam hubungannya dengan intensi berwirausaha. Dari pengolahan data sekunder tersebut, peneliti mendapatkan hasil bahwa tidak terdapat perbedaan yang signifikan antara kelompok subjek laki-laki dan kelompok subjek perempuan dalam intensi berwirausaha. Hal ini bertentangan dengan hasil penelitian Laviolette \& Radu (2008) yang menunjukkan bahwa laki-laki mengekspresikan intensi yang lebih kuat untuk berwirausaha dibanding perempuan Perbedaan hasil penelitian tersebut sangat mungkin disebabkan karena proporsi jumlah subjek perempuan dan laki-laki tidak berimbang, dimana subjek perempuan sebesar 76,2\% sedangkan laki-laki 23,8\%.

Hasil lain yang didapatkan peneliti adalah tidak ada pengaruh yang signifikan dari jenis model peran terhadap intensi berwirausaha. Dari hasil tersebut, dapat diinterpretasikan bahwa jenis model peran bukanlah faktor yang menentukan intensi berwirausaha, tetapi pembelajaran observasional yang dilakukan individu yang bersumber dari model peran itulah yang lebih menentukan intensi berwirausaha. Pengaruh jenis model peran langsung telah dikaji bertahun-tahun dalam literatur akademik. Sebaliknya, masih sangat sedikit penelitian yang mengkaji mengenai dampak model simbolik dalam intensi berwirausaha (Laviolette \& Radu, 2008). Sejumlah studi deskriptif mencatat pentingnya model langsung dalam pengambilan keputusan untuk memulai berwirausaha (Shappero \& Sokol dalam Laviolette \& Radu, 2008).

Dari hasil penelitian ini, diharapkan dapat memicu munculnya penelitian- penelitian yang berhubungan dengan model simbolik, karena model simbolik lebih dapat dimanipulasi dalam strategi intervensi kelompok. Dikatakan lebih dapat dimanipulasi karena model simbolik merupakan model yang tampil lewat media sehingga dapat diciptakan melalui paparanpaparan informasi di media. Oleh karena itu, dari hasil penelitian ini dapat dilakukan penelitian lanjutan mengenai variasi, cara dan frekuensi paparan model peran di media agar dapat diketahui strategi yang efektif untuk dapat menumbuhkan intensi berwirausaha melalui paparan model peran di media.

Hasil lain yang didapatkan adalah tidak adanya pengaruh yang signifikan dari suku bangsa terhadap intensi berwirausaha. Hasil ini bertentangan dengan pendapat Taniguchi (dalam Budig, 2006) yang menyatakan bahwa variabel suku bangsa turut mempengaruhi partisipasi seseorang dalam berwirausaha. Perbedaan hasil penelitian dengan pernyataan Taniguchi (dalam Budig, 2008) tersebut sangat mungkin disebabkan karena proporsi suku bangsa subjek dalam penelitian ini tidak terkontrol dengan baik. Dikatakan tidak terkontrol dengan baik karena dari data yang didapatkan, proporsi antara suku bangsa yang satu dengan yang lain tidak berimbang sehingga kurang representatif untuk mewakili suku yang ada.

Berdasarkan pengolahan statistik, peneliti menemukan bahwa tidak ada pengaruh yang signifikan antara pekerjaan orang tua dengan intensi berwirausaha. Hal ini diperkirakan dapat disebabkan oleh beberapa hal. Pertama, hasil tersebut mungkin disebabkan karena proporsi yang tidak cukup berimbang antara satu pekerjaan dan pekerjaan yang lain sehingga kurang representatif dalam mewakili pekerjaan yang ada. Kedua, pekerjaan orang tua bukanlah faktor yang berpengaruh signifikan terhadap intensi berwirausaha dalam diri seseorang.

Dalam penelitian ini, didapatkan hasil bahwa faktor pengalaman berwirausaha tidak memiliki pengaruh yang 
signifikan terhadap intensi berwirausaha. Proporsi kelompok subjek yang memiliki pengalaman berwirausaha dengan kelompok subjek yang tidak memiliki pengalaman berwirausaha dalam penelitian ini cukup berimbang. Hasil yang didapatkan dapat dimaknai bahwa pengalaman berwirausaha bukanlah faktor yang berpengaruh terhadap intensi berwirausaha.

\section{SIMPULAN}

Kesimpulan dari penelitian ini adalah terdapat hubungan antara pembelajaran observasional dan intensi berwirausaha. Indeks korelasi yang didapatkan adalah sebesar 0,562 dengan level kepercayaan 99\%. Dengan kata lain, variabel pembelajaran observasional dapat menjelaskan intensi berwirausaha sebesar 31,6\%. Dengan demikian, dapat dikatakan bahwa $68,4 \%$ intensi berwirausaha dapat dijelaskan oleh variabel-variabel lain diluar pembelajaran observasional. Lebih khusus, Indeks korelasi yang didapatkan dari tiap dimensi terlihat semakin meningkat dimana pada dimensi atensi memiliki indeks part correlation terkecil dan dimensi motivasi memiliki indeks part correlation. Dengan kata lain, semakin intens seseorang melakukan pembelajaran observasional, maka semakin besar kemungkinan munculnya pembelajaran observasional pada dirinya. Dikatakan semakin intens karena proses pembelajaran observasional merupakan proses yang berkelanjutan, dimulai dengan proses atensi, dilanjutkan proses retensi, kemudian proses produksi dan yang terakhir namun sangat menentukan adalah proses motivasi.

\section{SARAN}

\section{Saran Metodologis}

a. Untuk memperkaya hasil penelitian, sebaiknya jumlah subjek ditambahkan dengan proporsi yang berimbang antara perempuan dan laki-laki. Penambahan jumlah subjek dengan proporsi seimbang merupakan salah satu bentuk kontrol terhadap variabel jenis kelamin b. Subjek dalam penelitian ini terbatas pada usia 22-26 tahun. Usia tersebut dapat menggambarkan tahapan perkembangan dewasa awal (emerging adulthood) namun kurang dapat mewakili kelompok usia dewasa muda karena rentang usia dewasa muda berada pada 20 hingga 40 tahun. Oleh karena itu, untuk dapat melihat hubungan intensi berwirausaha dengan pembelajaran observasional pada dewasa muda, subjek penelitian hendaknya mewakili usia 20-40 tahun. Hal ini penting untuk dilakukan karena usia produktif untuk menjadi wirausaha bukan hanya pada dewasa awal, tetapi pada dewasa muda secara umum.

c. Dari hasil penelitian ini, terlihat bahwa jenis model tidak memiliki pengaruh yang signifikan terhadap intensi berwirausaha. Meskipun demikian, hasil ini dirasa kurang dapat dipertanggungjawabkan karena proporsi yang tidak berimbang antara kelompok subjek yang memiliki model peran langsung, model peran simbolik dan keduanya. Oleh karena itu, penelitian ini diharapkan dapat memicu penelitian berikutnya yang berfokus pada pengaruh model simbolik karena masih sedikit penelitian yang mengkaji tentang hal tersebut. Dengan mengetahui efektivitas model simbolik terhadap pembelajaran observasional, diharapkan dapat menjadi acuan dalam pembuatan strategi intervensi yang massive dalam rangka menumbuhkan intensi berwirausaha pada kaum muda Indonesia.

d. Dalam penelitian ini, fokus penelitian adalah pada pembelajaran observasional. Untuk dapat memperkaya hasil penelitian, sebaiknya variabel karakteristik model juga turut diteliti. Dengan mengetahui karakteristik model yang dimiliki masing-masing subjek, diharapkan penelitian berikutnya mendapatkan gambaran yang jelas mengenai karakteristik model yang banyak 
dijadikan rujukan. Dari gambaran tersebut, diharapkan dapat dibuat strategi intervensi yang efektif dalam rangka menumbuhkan pembelajaran observasional melalui pembelajaran observasional.

e. Dari data hasil penelitian ini, sebaiknya dilakukan analisis model untuk mendapatkan hasil yang lebih akurat mengenai kontribusi tiap dimensi dari variabel pembelajaran observasional terhadap intensi berwirausaha.

f. Partisipan dalam penelitian ini adalah mahasiswa. Untuk dapat mengetahui usia/fase yang paling efektif dalam memunculkan intensi berwirausaha, perlu dicari data mengenai kapan pada umumnya seseorang memutuskan untuk mulai berwirausaha, apakah saat lulus kuliah atau saat individu mulai merasa tidak puas dengan pekerjaan yang ia tekuni.

\section{Saran Praktis}

Dari penelitian ini, didapatkan hasil bahwa pembelajaran observasional melalui model peran berhubungan secara signifikan dengan intensi berwirausaha pada mahasiswa. Berdasarkan hasil tersebut, dapat dibuat strategi intervensi untuk memicu munculnya intensi berwirausaha pada kaum muda Indonesia, yaitu menyediakan model peran-model peran yang dapat dirujuk individu dalam proses pembelajaran observasional. Intervensi ini tidak cukup dilakukan secara momentual, misalnya dengan seminar saja, namun dibutuhkan proses yang intens bagi individu untuk melakukan proses-proses yang membentuk pembelajaran observasional.

Dari korelasi per dimensi pembelajaran observasional, didapatkan hasil bahwa dimensi motivasi merupakan dimensi yang paling berkontribusi terhadap intensi berwirausaha. Berdasarkan hasil tersebut, untuk meningkatkan intensi berwirausaha melalui pembelajaran observasional, hendaknya yang ditonjolkan dari model peran adalah insentif-insentif yang didapatkan dari berwirausaha.
Secara praktis, hasil penelitian ini dapat dimanfaatkan pihak-pihak terkait untuk menumbuhkan intensi berwirausaha pada kaum muda di Indonesia dengan memperhatikan proses-proses pembelajaran observasional yang memberikan kontribusi besar terhadap pembelajaran observasional.

\section{DAFTAR PUSTAKA}

Anastasi, Anne \& Urbina, Susan. (1997). Psychological Testing, $7^{\text {th }} E d$. New Jersey: Prentice Hall

Ardias, W.S. (2008). Pengaruh Orientasi Masa Depan di Bidang Karir, Pendidikan dan Pernikahan Terhadap Resiliensi pada Remaja Miskin. Depok: Fakultas Psikologi Universitas Indonesia.

Bandura, Albert. (1986). Social Foundations of Thought \& Action: A Social Cognitive Theory. New Jersey: Prentice-Hall.

Feist, Jess \& Feist, Gregory J. (2006). Theories of Personality 6th Ed. Singapore: McGraw-Hill.

Garo, E., Kume, F \& Basho, S. (2015). Role Model's Effect on Students Enterpreneurial Intention. Proceedings of the 15th International Academic Conference, p. 340-340

Hisrich, R, Peter, M \& Sheperd, D. (2005). Entrepreneurship $6^{\text {th }}$ ed. New York: McGraw-Hill, Inc.

Hisrich, R, Peter, M \& Sheperd, D. (2008). Entrepreneurship $7^{\text {th }}$ ed. New York: McGraw-Hill, Inc.

Kountur, R. (2003). Metode Penelitian Untuk Penulisan Skripsi dan Tesis. Jakarta: CV Teruna Grafika.

Kumar, Ranjit. (1999). Research Methodology: a Step-by-step Guide for Beginners. New Delhi: SAGE Publications Ltd.

Laviolette \& Radu. (2008). Symbolic Role Models and Entrepreneurial Intention. International Council for Small Bussiness Conference.

Linan, dkk. (2005). Faktors affecting entrepreneurial intention levels. Amsterdam : 45th Congress of the European Regional Science Association.

Linan, F. (2008). Skill and Value Perception: How Do They Affect Entrepreneurial Intention. Journal of Int Entrep Manag J4:257-272. 
Linan, Francisco \& Chen, Y.W. (2006). Testing The Entrepreneurial Intention Model on A Two-Country Sample.

Ormrod, J. E. (2006). Educational Psychology $5^{\text {th }}$ ed. Ohio: Pearson

Ormrod, J. E (1999) Human learning (3rd edition), Sydney, New South Wales: Merrill, Prentice Hall Australia Pty Ltd

Riyanti, Benedicta P D. (2008). Metode Experiential Learning Berbasis Pada Peningkatan Rasa Diri Mampu, Kreatif \& Berani Beresiko dalam Mata Pelajaran Kewirausahaan untuk SMK. Jakarta: Fakultas Psikologi Universitas Atmajaya.

Sudrajat. (2003). Kiat Mengentaskan Pengangguran melalui Wirausaha. Jakarta: Bumi Aksara 